\title{
Participation of Rural Garo Women of Meghalaya in Vegetable Cultivation
}

\author{
Swapnali Borah* and Nilakshi Borah \\ College of Community Science, Central Agricultural University, Tura, \\ Meghalaya - 794005, India \\ *Corresponding author
}

\section{A B S T R A C T}

Keywords

Garo farm women, Vegetable cultivation, Shifting cultivation, Unnatural posture, Musculoskeletal problem

\section{Article Info}

Accepted:

15 December 2020

Available Online:

10 January 2021
Meghalaya is one of the most scenic states of India, where rural tribal farm women of Meghalaya are contributed to agricultural work in addition to household activities. The study was conducted among 80 female and 20 male Garo women farmers with the age group of 20-50 years who were actively participated in different activities of vegetable cultivation were selected by purposive sampling procedure from two villages namely Aminda Rangsagre and Aminda Simsanggre of Gambegre block of West Garo Hills districts of Meghalaya. The results revealed that most of rural farm women participated in several activities under vegetable cultivation where they affected by work related hazards and difficulties in different parts of body due to adopted unnatural posture, continuous working pattern and sometimes repetitiveness nature of work.

\section{Introduction}

In rural India, above 84 percent of women who depend on farming for their livelihood where about $47 \%$ percent are agricultural laborers and about $33 \%$ are cultivators (Rao, 2006). Also women play a farm significant and key role in production of vegetable (Kumari, Anuradha Ranjan and Laxmikant, 2015). The women of Meghalaya was not exceptional they also play numerous role in vegetable cultivation as well as their household works. Though majority of women in rural areas are illiterates, unskilled and most of are traditionally bound. On the other hand, they contribute to agriculture and rural development (Nakwe et al.2018). Some of the agricultural activities performed by rural women including manure application, planting/sowing, weeding, irrigation, harvesting, transporting, livestock management etc. In Meghalaya cultivation of vegetable is more than other crop cultivation because of hilly region and the favorable agro climatic condition. 
As most of the activities under vegetable cultivation are done manually and by using traditional age old tools like khurpi, dao, hoe, sickle, spade, pickaxe etc. which is unsuitable to their body anthropometry as these were meant for men. Women are also responsible for harvesting and transporting vegetables from field to home and home to market. While transporting vegetables farm women are using a native bamboo basket called "kokcheng" which are carried on their back with a load of vegetables up to $30-35 \mathrm{~kg}$ and it is very much strenuous for them. While carrying out all the activities women farmers were complain about tiredness and fatigue due to laborious and tedious. Rural tribal farm women were also affected by some work related hazards, pain in back, lower limb and other body parts due to adoption of unnatural body posture, continuous working pattern, and repetitive motion of some body parts. For that reason to reduce work related hazards some ergonomically suitable tool was modified and adopted which was given to the hilly farm women for performing different activities related to vegetable cultivation.

In Meghalaya the ethnic communities follow two types of farming practices such as shifting cultivation (Jhum) and terrace cultivation (Solomon et. al 2006). Shifting cultivation is the most usual form of agricultural practice and covering different forms of land use. After selected a part of land, trees or shrubs are cut down partly or fully, left to dry and then burnt in the same area. In the empty land, seeds of crops are dibbled into holes, without using ploughs or animal power. When the crop yield begins to reduce after some years, the cultivator selected another land to repeat the process, and allows the abandoned land to recuperate. After a period varying from 2-20 years, they return to the same land for cultivation (Okigbo B.N, 1984). Generally, people who live in hilly tropical region like Meghalaya practice shifting cultivation. This cultivation practice has socio economic relevance for production of agricultural crops in Meghalaya. There is no alternate means of livelihood for the ethnic peoples of the Garo Hills of Meghalaya because of their poor economic condition. Vegetable cultivation is one of the prime agricultural activities which includes pumpkin, squash (Sechium edule), bottle gourd, bitter gourd, cabbage, cauliflower, lemon, okra, chilies, ginger, turmeric etc. where mainly women are involved.

\section{Materials and Methods}

A total of 80 female and 20 male farmers with the age group of 20-50 years who were actively participated in different activities of vegetable cultivation were selected by purposive sampling procedure from two villages namely Aminda Rangsagre and Aminda Simsanggre of Gambegre block of West Garo Hills districts of Meghalaya. The activity of vegetable cultivation was selected purposively as most of the households ware involved in this cultivation. Though rice is staple food of Garo tribe but in this region they are mostly engaged in vegetable cultivation due to hilly terrain. Interview schedule was developed to collect the data on participation of the respondents under different activities related to vegetable cultivation. Simple average and percentage were used to analyze collected data for the study.

\section{Results and Discussion}

\section{Women's participation in land preparation and weed management activities}

From the Table 1 and Fig 1 it is observed that most of the rural women farmers involved in manure application (48\%) \& forming ridges and furrow $(59 \%)$. In contrary 47 percent 
male farmers were involved in ploughing activity under vegetable cultivation. Various studies reported that non participation of women in ploughing and forming ridges and furrows due to hard work, lack of awareness and knowledge (Kumari et al, 2015 and Srivastava and Singh, 2011). As respondents were mainly used hoe, pick axe and spade in land preparation (i.e. ploughing, manure application and forming ridges and furrow) they were having discomfort in lower back, upper back, lower arm and upper arm which was severe to very severe by using primitive type of agricultural tools. In case of weeding activity most of the women farmers involved in hand weeding as compared to spraying weedicide. Another study done in Nigeria in the year 2018 where women perform such type of works like hoeing, sowing, weeding, harvesting particularly in food crops and women are mainly growing of crops like cassava, cocoyam, maize and vegetables (Nakwe et al, 2018). Hand weeding activity was repetitive in nature and adopted squatting posture and doing this activity with their traditional age old tool like 'khurpi and sickle' in which wrist, upper arm, lower back and upper back are affecting due to repetitive job. Weeding is a major problem for farm women. Verma et. al (2019) also opined that majority of the farm women do weed control using hand tools like sickle and khurpi only. Borah and Borah in the year 2020 revealed that female involvement is more than male in weeding activity and they were having pain in neck, trunk and upper limb due to prolonged squatting position at the time of weeding operation which may results in musculoskeletal disorders. Sharma (1999) also reported that while doing weeding with a traditional method women farmer adopted squatting and bending posture and continue it for long hours which can cause musculoskeletal disorders. At the time of spraying weedicide in vegetables, respondents were felt discomforts in lower arm, upper arm, shoulder and neck due to carrying load of spray weedicide machine for long hours.

Participation of the respondents in harvesting and transportation activities

After analysis of the data (Table $2 \&$ Fig 2) it is observed that in case of harvesting majority of female farmers involved in cutting (45 percent), sorting (47 percent) and cleaning (71 percent), in compared to male farmers. Only 22 percent, 14 percent and 9 percent male farmers were involved in cutting, sorting and cleaning, respectively while harvested vegetables. These finding is in conformity with the researchers Baba et al. (2010) and he found from their study that in Jammu and Kashmir also women were involved in case of harvesting and transporting vegetables. Pattanaik (1994) also opined that in rural area farm women were involved in harvesting and storage of grain. At the time of harvesting, farm women of Meghalaya were using some primitive tools as well as a kind of native bamboo basket known as kokcheng for carrying harvested vegetables to home as well as to village market. Farm women felt severe pain in different parts of their body which was due to using of old tools along with adoption of unnatural posture. While doing transporting vegetables majority of the women farmers involved carrying and loading activities as compared to male farmers. Previous study done by Nakwe et al in the year 2018 on assessment of women participation in vegetable production and results showed that 91.76 percent of them fully participated in the transportation of vegetable and 95.05 percent were engaged in the marketing of vegetable in Nigeria. The carrying and loading activity was severe to very severe in which upper and lower back felt discomfort and adopted bending posture because they used to carrying harvested vegetables from farm to home or farm to market by using kokcheng (a kind of 
traditional bamboo basket) up to $30 \mathrm{~kg}$, but sometimes they carried 35 to $40 \mathrm{~kg}$ for long distance in hilly terrain. Such type of heavy load may put pressure on back and vertebral column and cause musculoskeletal disorders like cervical pain, back pain etc. Borah and Borah (2020) reported that the women workers engaged in sericulture industries of East Garo hills districts of Meghalaya perceived the rearing of silkworm activity as 'heavy to very heavy' because they are used to carrying a heavy load of Castor/ Kesseru leaves up to $25 \mathrm{kgs}$ on their back to rearing house to feed the larvae. They carry loads of Castor/ Kesseru leaves in their kokcheng (A kind of traditional bamboo basket). It is in conformity with Borah (2015), who found that women carrying heavy load of firewood from forest perceived it as heavy to very heavy.

\section{Participation of the respondent in planting/sowing activity}

While doing planting/sowing activity majority (Fig 3) of the Garo women farmers of were involved in this activity and again Nakwe et. al in the year 2018 found that 98.35 percent of the women farmers were involved in planting of vegetables Nigeria also. Farm women adopted bending and squatting posture which affected lower and upper arm due to use of age old farm tool and long hours of working pattern.

Participation of the respondent in fertilizer application activity

After analysis of the data (Fig 4) it was showed that 53 percent of both male and female farmers involved in fertilizer application under vegetable cultivation. Earlier study done on participation of rural women in vegetable cultivation of Deoria districts in Utter Pradesh and results showed that above fifty per cent of women involved in fertilizer application and nursery management while 21.66 and 24.16 per cent were participated in seed treatment and raising vegetable nursery respectively (Kumari, Anuradha Ranjan and Laxmikant 2015). While doing this activity they were adopted bending and squatting posture which affected their upper back, lower back and upper extremities.

\section{Participation of the respondent in irrigation activity}

Participation of the respondent in irrigation activity under vegetable cultivation was presented in Fig 5. It was observed that 60 percent of the both male and female rural farmers engaged in irrigation activity. Nakwe et al (2018) revealed that 54.95 percent farm women actively participated in irrigation of the vegetable. Rural farm women of Meghalaya were using some conventional tool while doing irrigation where farmers can severely affect their shoulder, upper and lower arm. Hasalkar et. al (2017) also reported that the majority of the women complained very severe to severe pain in shoulder joint, upper arm, low back, wrist/hands and knees while performing top dressing of fertilizer by traditional tool compared to improved tool.

\section{Participation of the respondent in weeding (row to row) activity}

From the Fig 6 it can be observed that most of the Garo women farmers participated in row to row weeding where they adopted unnatural posture while doing this activity. According to Singh et. al (2017) weeding is an agricultural activity of removal of unnecessary plants by hand or with the help of traditional tool like khurpi and kudali. Only 8 percent male farmers involved in this activity as compared to female farmers. 
Table.1 Participation of the respondents in land preparation and weed management activities under vegetable cultivation

\begin{tabular}{|l|c|c|c|c|c|c|c|}
\hline \multicolumn{1}{|c|}{ Activities } & \multicolumn{2}{|c|}{ Male } & \multicolumn{2}{c|}{ Female } & \multicolumn{2}{c|}{ Both } \\
\hline & Frequency & $\%$ & Frequency & $\%$ & Frequency & $\%$ \\
\hline Land preparation & 47 & 47 & 32 & 32 & 21 & 21 \\
\hline 1. Ploughing & 25 & 25 & 48 & 48 & 27 & 27 \\
\hline $\begin{array}{l}\text { 2. Manure application } \\
\text { 3. Forming ridges and } \\
\text { furrows }\end{array}$ & 32 & 32 & 59 & 59 & 9 & 9 \\
\hline $\begin{array}{l}\text { Need management } \\
\text { 1. Spraying weedicide }\end{array}$ & 63 & 63 & 14 & 14 & 23 & 23 \\
\hline 2. Hand weeding & 7 & 7 & 78 & 78 & 15 & 15 \\
\hline
\end{tabular}

Table.2 Participation of the respondents in harvesting and transportation activities under vegetable cultivation

\begin{tabular}{|c|c|c|c|c|c|c|}
\hline \multirow[t]{2}{*}{ Activities } & \multicolumn{2}{|c|}{ Male } & \multicolumn{2}{|c|}{ Female } & \multicolumn{2}{|c|}{ Both } \\
\hline & Frequency & $\%$ & Frequency & $\%$ & Frequency & $\%$ \\
\hline \multicolumn{7}{|l|}{ Harvesting } \\
\hline 1. Cutting & 22 & 22 & 45 & 45 & 33 & 33 \\
\hline 2. Sorting & 14 & 14 & 47 & 47 & 39 & 39 \\
\hline 3. Cleaning & 9 & 9 & 71 & 71 & 20 & 20 \\
\hline \multicolumn{7}{|c|}{ Transporting } \\
\hline 1. Carrying & 8 & 8 & 74 & 74 & 18 & 18 \\
\hline 2. Loading & 8 & 8 & 66 & 66 & 26 & 26 \\
\hline
\end{tabular}

Fig.1 Participation of the respondents in land preparation and weed management activities under vegetable cultivation

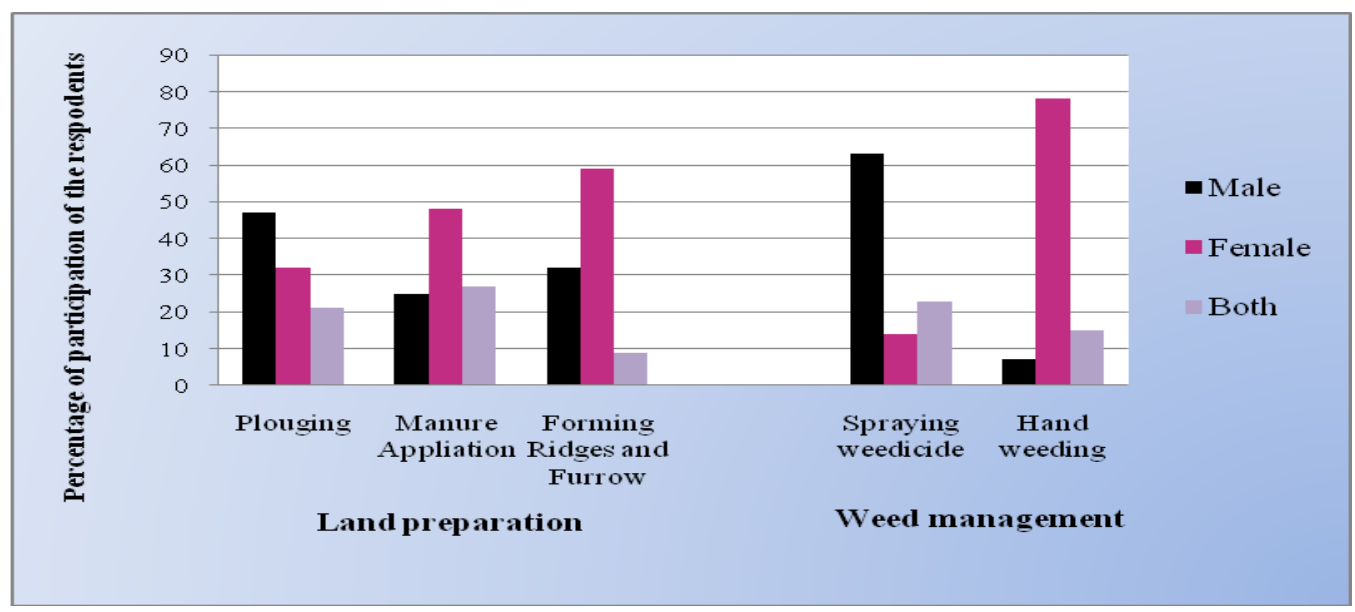


Fig.2 Participation of the respondent in harvesting and transporting activities under vegetable cultivation

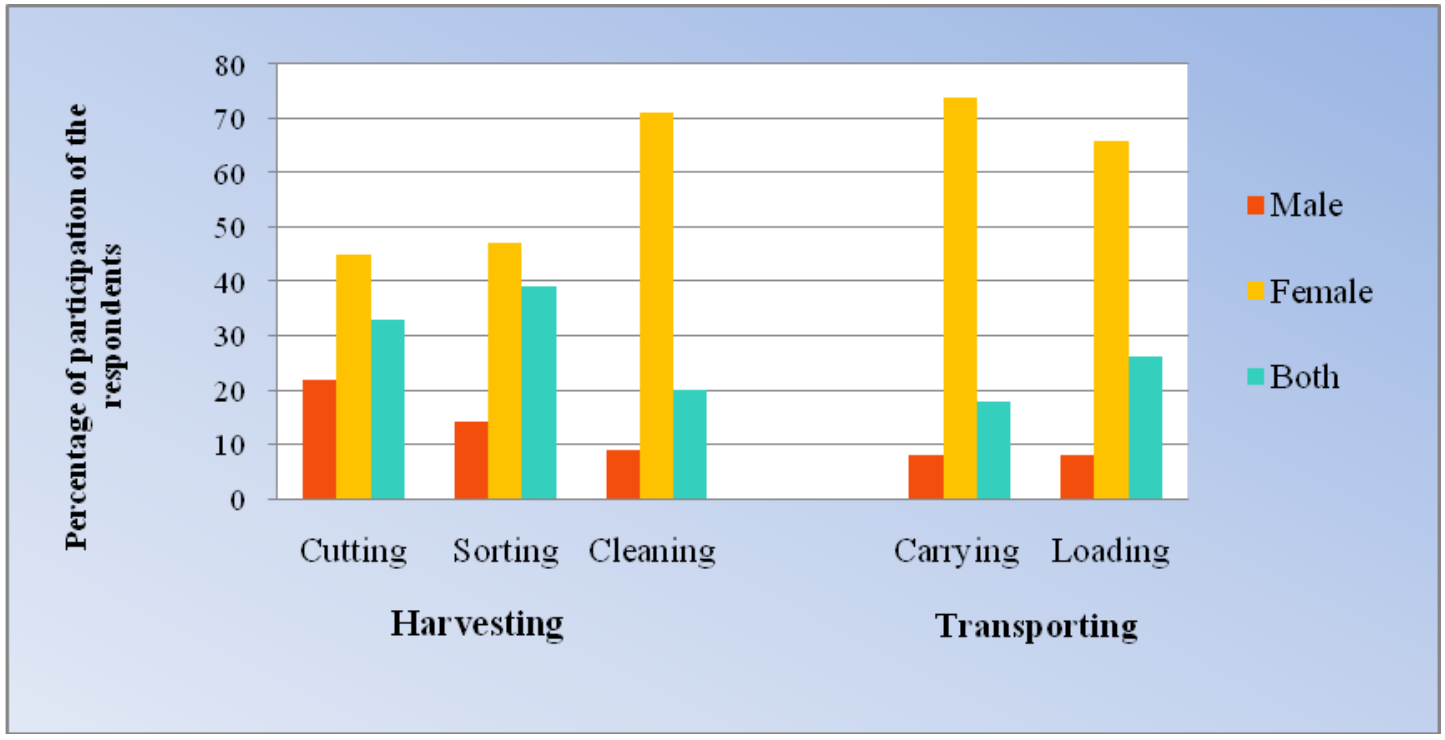

Fig.3 Participation of the respondent in planting/sowing activity under vegetable cultivation

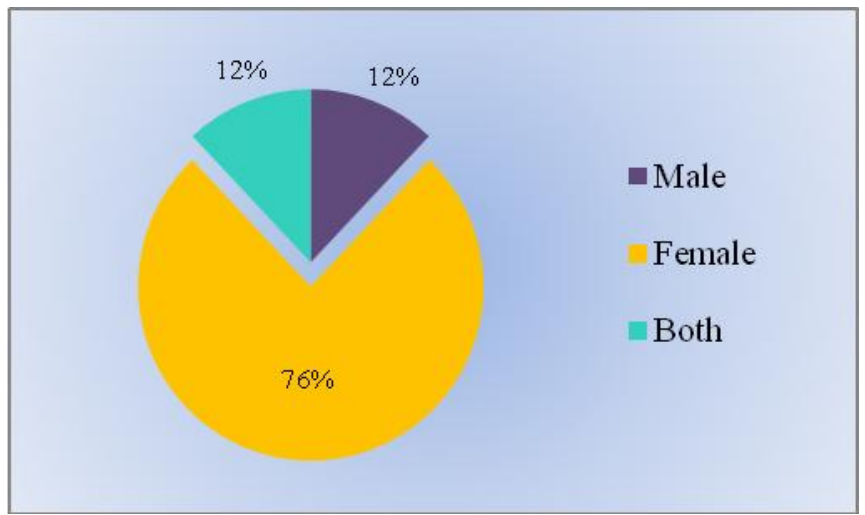

Fig.4 Participation of the respondent in fertilizer application activity under vegetable cultivation

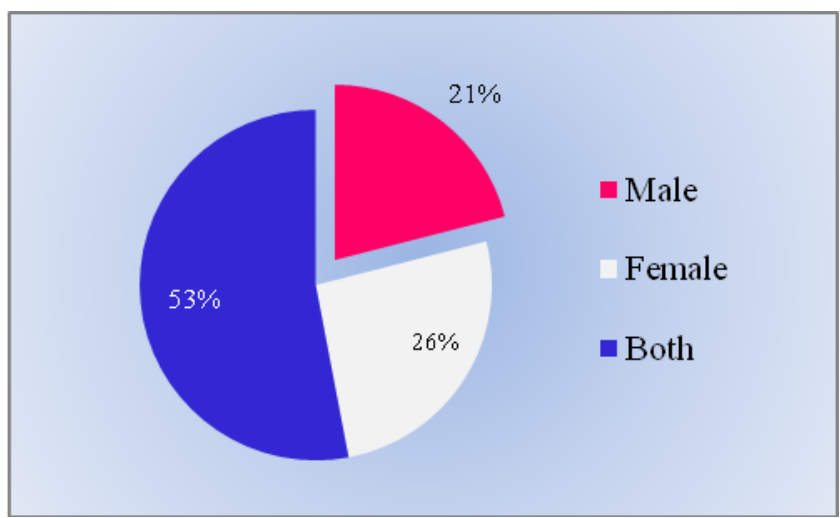


Fig.5 Participation of the respondent in irrigation activity under vegetable cultivation

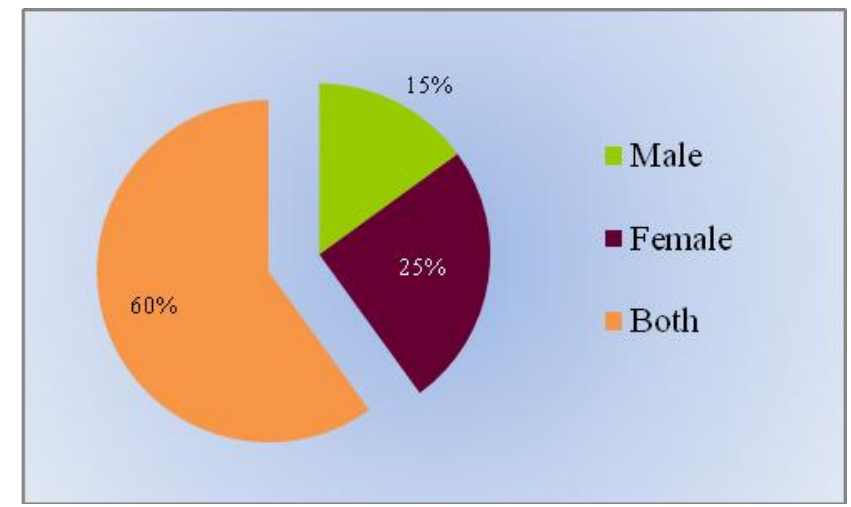

Fig.6 Participation of the respondent in weeding (row to row) activity under vegetable cultivation

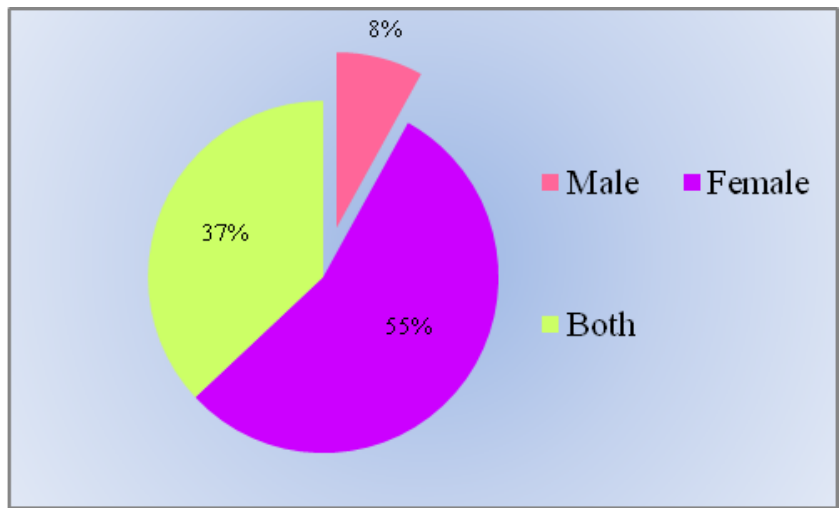

In conclusion, Meghalaya is a state having sandy and rocky loom with high precipitation rate. Soil and climatic condition is suitable for many vegetables and horticultural crops. It is observed that most of the women are involved in manure application, forming ridges and furrow, planting/sowing, hand weeding, harvesting, transporting etc. under vegetable cultivation along with household chores and animal husbandry work which was very tedious, some are repetitive nature of work as well as drudgery prone and they suffer lots of work related health hazards. While participating in different activities under vegetable cultivation women were using some primitive type of agricultural tool which were not suitable for their body as these were meant for man. To minimize drudgery some ergonomically designed women friendly tools like khurpi, sickle, standing pick axe, spade, standing rake, improved kokcheng etc were modified and tested by women farmers in the field and recommended to farm women for using so that drudgery can be reduced as well as decreased the work related musculo skeletal problems.

\section{Acknowledgement}

This is a part of the project of AICRP-Home Science (FRM component), funded by CIWA, ICAR, Bhubaneswar.

\section{References}

Baba, S.H., Bilal, A. Zargar, Ganaie, S.A., Yousuf, Shoaib and Sher, Huma (2010). Gender participation in Kashmir valley. 
Indian Res. Ext. Edu., 10(2):60-66.

Borah S. and Borah N (2020) Prevalence of Ergonomics Risks and Health Hazards in Sericultural Activities Performed by Hilly Tribal Women of East Garo Hills of Meghalaya, India. Anthropologist, 39(1-3): 9-16

Borah, S. (2015) Physiological workload of hill farm women of Meghalaya, India involved in firewood collection. Procedia Manufacturing, Elsevier, 3: 4984-4990.

Borah, S. and Borah N (2020) Ergonomic Assessment of Upper Limbs of Workers Involved in Vegetable Cultivation. Int.J.Curr.Microbiol.App.Sci. $\quad 9(05)$ : 3201-3207.

Haslkar S, Shivalli R, and Budihal R (2007) Musculoskeletal disorder of the farm women while performing top dressing and fertilizer activity. Journal of Human Ecology 21(2): 109-112.

Kumari, A. R. and Laxmikant (2015) Participation of rural women in vegetable production. Adv. Res. J. Soc. Sci., 6 (2):258-260.

Nakwe S. H. G, Mahmood H. U, Ndaghu A. A, Bashir M. B, and Kyaru M. T (2018) Assessment of Women Participation in Vegetable Production Activities in ADP, Zone III, Taraba State, Nigeria Asian Journal of Agricultural Extension, Economics \& Sociology., 27 (2):1-16.

Okigbo B.N (1984) Improved permanent production systems as an alternative to shifting intermittent cultivation, FAO
Soils Bull, 53,100.

Pattanaik, J. (1994) A Study Related to Participation of Rural Farm Women in Agricultural Activities, Social Change, 21(7-8): 23-29.

Rao, E. K (2006) Role of Women in Agriculture: A Micro level study. Journal of Global Economy. 2(2):107118.

Sharma, V. (1999). Ergonomics assessment of weeding activity with conventional and modified tool. M.Sc. Thesis, Department of Family Resource Management, College of Home Science, Maharana Pratap University of Agriculture \& Technology, Udaipur, RAJASTHAN (INDIA).

Singh, S., Mathur, P. and Ratore, M. (2007). Weeders for drudgery reduction of women farm workers in India.J.Agric.Engg.,44 (3): 33- 38.

Solomon RDNJ, Roytre Christopher Laloo, and Mishra Bhanu Prakash (2006) Traditional agricultural practices in Meghalaya, North East India. Indian Journal of Traditional Knowledge. 5(1):7 18 .

Srivastava, P.L. and Singh B.P (2011) Role of housewives and agricultural farm female farm labourers in agricultural operations. J. Progress. Sci., 2 (1):7073.

Verma R, and Singh V (2019) Health Problems Faced by Farm Women during Weeding Activity. Indian Journal of Ecology Special Issue-1: 000-000, Manuscript Number: 2821.

\section{How to cite this article:}

Swapnali Borah and Nilakshi Borah. 2021. Participation of Rural Garo Women of Meghalaya in Vegetable Cultivation. Int.J.Curr.Microbiol.App.Sci. 10(01): 2321-2328.

doi: https://doi.org/10.20546/ijcmas.2021.1001.269 